\title{
Signature patterns of DNA restriction fragments of Helicobacter pylori before and after treatment
}

\author{
R J Owen, J Fraser, M Costas, D Morgan, D R Morgan
}

\begin{abstract}
The genomic DNA of Helicobacter pylori was studied by electrophoretic analysis of restriction endonuclease fragments. Twenty seven isolates from eight patients in the United Kingdom, obtained before and after treatment with nitrofurantoin, and two reference strains from Australia and Peru were investigated. Digestion of DNA with HaeIII, which gave the clearest band pattern of the 20 enzymes tested, showed that each set of isolates from a single patient had a unique band pattern. The DNA signature band patterns of strains from different patients were $\leqslant 62 \%$ similar (average $43 \%)$; similarities of patterns from the same patient were generally $\geqslant 86 \%$. Some minor but reproducible polymorphisms ( $\leqslant$ five bands) in the signature region were detected in most consecutive isolates. Plasmid DNA was detected in isolates from five patients, but major pattern differences were attributed to genomic variation.

It is concluded that the HaeIII DNA digest signature fingerprints provide a reproducible and sensitive method of discriminating between isolates of $H$ pylori.
\end{abstract}

Helicobacter pylori is a spiral-shaped bacterium, previously named Campylobacter pylori, that is isolated from the stomach and duodenum of patients with and without symptoms of gastric disease. ${ }^{1}$ The organism is encountered worldwide and infects at least $25 \%$ of the adult population. ${ }^{2}$ Its ability to colonise the antral epithelium of the stomach is strongly associated with non-autoimmune, type B gastritis and peptic ulcer disease in adults and children. ${ }^{34}$ Elimination of the organism results in the healing of gastritis and ulcer disease. Relapse of gastroduodenal disease occurs in about $80 \%$ of cases and is associated with recrudescence of infection. The precise role of $H$ pylori as an aetiological agent, however, remains controversial. ${ }^{5}$

The epidemiology of $H$ pylori remains largely unknown. Man is the most likely natural reservoir, and spread possibly occurs by person-to-person transmission of the bacterium. ${ }^{2}$ The study of infections by $H$ pylori is hindered by the lack of suitable serological and other typing methods, despite the fact that strains differ in several respects. These include cytotoxic ${ }^{67}$ and haemagglutinating activity $^{8}$; immunoblot ${ }^{9}$ and polyacrylamide gel electrophoresis protein fingerprints ${ }^{10}$; plasmid profiles $^{1112}$; and genomic DNA restriction endonuclease digest patterns. ${ }^{13-15}$ The latter seem to be highly discriminatory with isolates from different patients, almost all exhibiting unique profiles. ${ }^{13-15}$

In this study we examined the usefulness of partial, herein called signature, DNA restriction digest electrophoretic band patterns as a basis for characterising sets of multiple isolates of $H$ pylori obtained from patients before and after treatment to determine if the same strains persisted. A range of different restriction endonucleases was examined.

\section{Methods}

The 27 clinical isolates from eight patients (designated $\mathrm{A}$ to $\mathrm{H}$ in this study) were obtained from gastric tissue collected during endoscopy and biopsy of patients with symptoms of dyspepsia and histologically confirmed gastritis. Cultures were provided by the Public Health Laboratory, Withington Hospital, Manchester. Most of the strain sets comprised two isolates (I and II) collected on the same day from two adjacent sites in the antrum and two further isolates (III and IV) from the antrum on subsequent biopsy four weeks later after receiving nitrofurantoin four times daily. Patients were treated with $50 \mathrm{mg}$ Furadantin oral suspension (microcrystalline drug) or $75 \mathrm{mg}$ Macrodantin capsules (macrocrystalline drug) at each dose. Reference strains NCTC 11638 $=$ RPH 13491) from Perth (Australia) and NCTC 12245 (= NEPI 95) from Lima (Peru) were obtained from the National Collection of Type Cultures (NCTC); both of these cultures originated from human gastric mucosa.

Organisms were grown routinely on Oxoid brain heart infusion agar supplemented with $5 \% \mathrm{v} / \mathrm{v}$ horse blood and $1 \%$ Isovitalex for 48 hours at $37^{\circ} \mathrm{C}$ in microaerobic conditions (5\% oxygen; $5 \%$ carbon dioxide; $2 \%$ hydrogen; $88 \%$ nitrogen) in a Variable Atmosphere Incubator (Don Whitley Scientific Ltd, Shipley, Yorkshire). Strains were preserved at $-196^{\circ} \mathrm{C}$ on glass beads in Nutrient Broth No 2 (Oxoid: CM67) containing 10\% (v/v) glycerol.

Chromosomal DNA was isolated and purified using the guanidium thiocyanate reagent method. ${ }^{16}$

DNA DIGESTION AND ELECTROPHORETIC

SEPARATION OF FRAGMENTS

DNA from NCTC 11638 was incubated with 20 different restriction endonucleases using 
the buffers and the conditions recommended by the manufacturer (Northumbria Biologicals Limited, Cramlington, Northumbria). All DNA samples $(5 \mu \mathrm{g})$ were then digested for four hours at $37^{\circ} \mathrm{C}$ with $\mathrm{HaeIII}(2-3 \mathrm{U} / \mu \mathrm{g}$ of DNA). The digested DNA (10-20 $\mu \mathrm{l})$ was electrophoresed at $25 \mathrm{~V}$ for 16 hours in a horizontal $0.7 \%(\mathrm{wt} / \mathrm{vol})$ agarose gel in a buffer containing $89 \mathrm{mM}$ TRIS-hydrochloride, $89 \mathrm{mM}$ boric acid, and $2 \mathrm{mM}$ disodium EDTA (pH 8.3). After electrophoresis the gels were stained with ethidium bromide and photographed as described previously. ${ }^{17}$

\section{ESTIMATION OF BAND SIZE}

The photographic negatives of the gels were scanned (Ultroscan laser densitometer; LKB, Bromma, Sweden), migration distances recorded, and fragment sizes calculated by the DNA-SIZE program, as described previously. ${ }^{17}$ HindIII bacteriophage $\lambda$ DNA digests were used to provide molecular weight markers.

\section{ESTIMATION OF SIMILARITIES BETWEEN \\ SIGNATURE PATTERNS}

The degree of similarity between different restriction endonuclease signature patterns (these comprised a subset of bands with sizes of more than 3.7 kilobase pairs) was expressed by the Dice coefficient (SD) and calculated by the formula $2 n_{x y} / n_{x}+n_{y}$, where $n_{x y}$ was the number of shared bands, and $n_{x}$ and $n_{y}$ were the numbers of bands in signature patterns $x$ and $y$, respectively. ${ }^{18}$ Bands were recorded as identical if their sizes agreed to within $\pm 0 \cdot 1$ kilobase on the same or different gels.

\section{PLASMID DNA EXTRACTION AND}

ELECTROPHORESIS

Organisms were cultured as described above. Single colonies were picked and plasmid

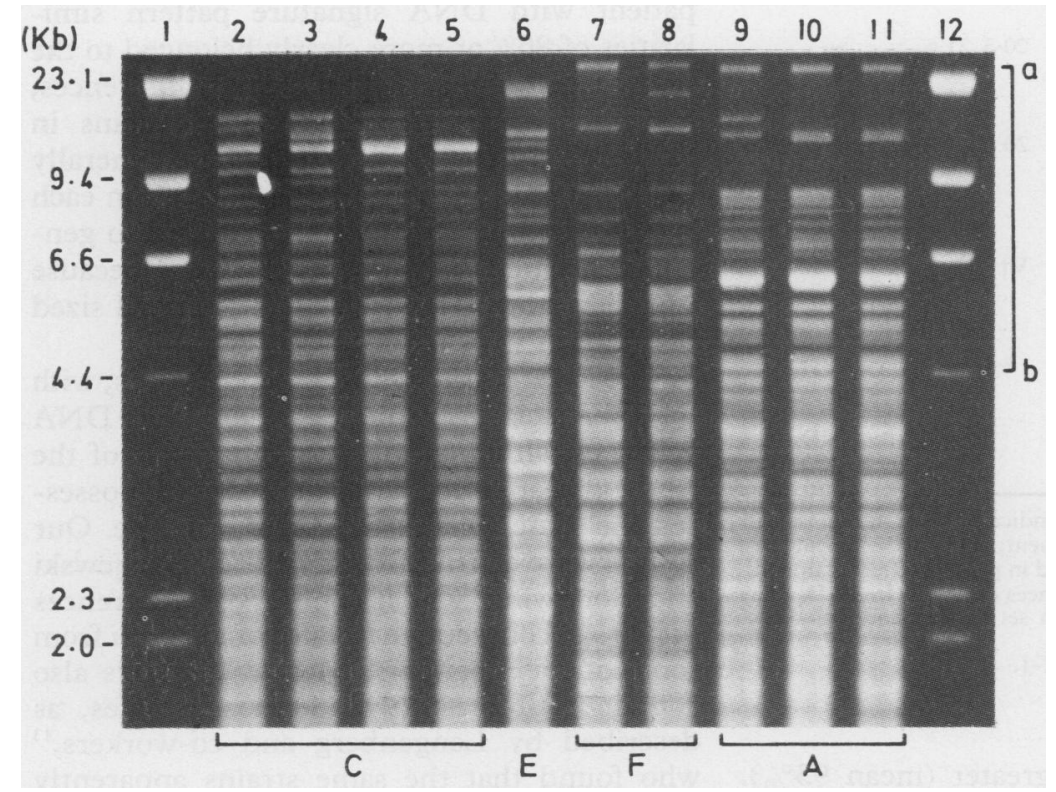

Figure 1 Agarose gel electrophoresis of chromosomal DNA restriction fragments of Helicobacter pylori digested with HaeIII. From left to right: lanes 1 and 12, bacteriophage $\lambda$ HindIII digest; lanes 2-5, patient set $C$ isolates; lane 6, patient $E$ isolate; lanes 7 and 8, patient set $F$ isolates; lanes $9-11$, patient set $A$ isolates. The region used as a signature pattern is indicated by line a to $b$.
DNA was prepared by the method of Kado and $\mathrm{Liu}^{19}$ but modified as follows. Cells were suspended in $250 \mu \mathrm{l}$ of $3 \%$ SDS at pH 12.5 and incubated at $55^{\circ} \mathrm{C}$ for 90 minutes. An equal volume of phenol/chloroform mixture was added with thorough mixing. The mixture was then centrifuged at $12000 \times g$ for 15 minutes at $4^{\circ} \mathrm{C}$. Plasmid preparations were stored at $4^{\circ} \mathrm{C}$ until required. Twenty microlitres of the supernatant fluid were mixed with $5 \mu$ l of dye solution and electrophoresed in a horizontal $0.7 \%$ agarose gel for two hours at $100 \mathrm{~V}$. After staining with ethidium bromide the gels were viewed in an ultraviolet transilluminator and photographed. Standard plasmids in Escherichia coli K12 hosts were used to determine molecular weights.

\section{Results}

DNA from $H$ pylori NCTC 11638 was cut to varying degrees by nine restriction endonucleases (BamHI, BstEII, EcoRI, HaeIII, HindIII, MspI, PvuII, SacI and StuI), but HaeIII (recognition sequence GG.CC) and HindIII (recognition sequence A.AGCTT) gave the clearest and most distinctive patterns of bands. HaeIII was selected to study all strains because it gave DNA patterns containing a region of 10 to 18 well resolved bands with sizes of more than or equal to 3.6 kilobases, which was used as the signature pattern for strain characterisation. The remainder of the pattern, which comprised less clearly resolved bands, was not examined in further detail. $M s p I$ yielded a distinct band pattern for NCTC 11638, but further tests showed that it did not cut DNA of all the strains of $H$ pylori. The following 11 endonucleases failed to cut NCTC 11638 DNA: AccI; AluI; ApaI; BscI; CfoI; PstI; RsaI; SacII; SalI; SphI; and TaqI.

DNA was extracted from the sets of two to four isolates of $H$ pylori from the eight patients $(\mathrm{A}-\mathrm{H})$ and was digested with HaeIII. Isolates within each set generally had very similar electrophoretic band patterns (figs 1 and 2), but were clearly different from members of other sets. Their DNA patterns were assigned the type designations given in table 1 . An example of densitometric scans of DNA digests after electrophoresis is shown in fig 3. Isolates that exhibited minor band differences were assigned to subtypes, and the sizes of the distinguishing bands are listed (table 1). Six of the eight sets comprised isolates of just one or two subtypes, although the sets from patient $D$ and $G$ were more heterogeneous with four or three subtypes in each, respectively. Seventeen isolates contained a plasmid within the 2.4 to 7.7 megadalton range (table 1). Generally, members of sets from individual patients were homogeneous with respect to plasmid content and size. Only in sets $\mathrm{D}$ and $\mathrm{H}$ were there minor strain differences in plasmid content.

Table 2 summarises the results of the estimated similarities between the patterns based on the numerical analysis of the signature band region. Most (seven of eight) sets showed similarities between members of the same 


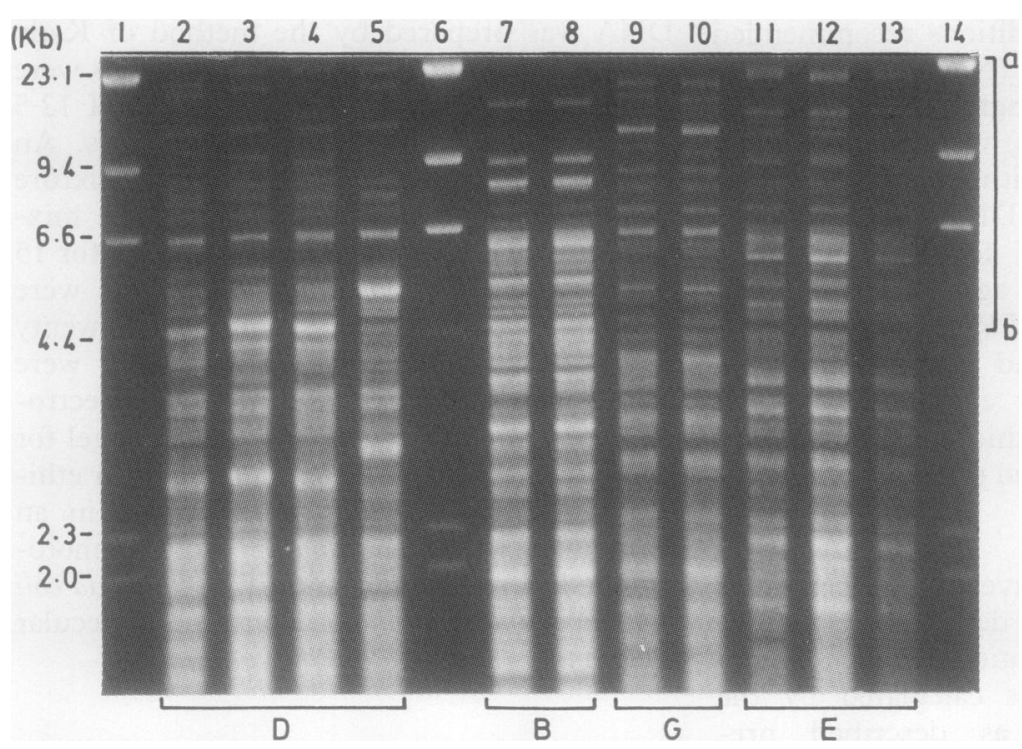

Figure 2 Agarose gel electrophoresis of chromosomal DNA restriction fragments of Helicobacter pylori digested with HaeIII. From left to right: lanes 1, 6, and 14 bacteriophage $\lambda$ HindIII digest; lanes 2-5, patient set $D$ isolates; lanes 7 and 8, patient set $B$ isolates; lanes 9 and 10 , patient set $G$ isolates; lanes 11-13, patient set $E$ isolates. The region used as a signature pattern is indicated by line a to $b$.

Table 1 Strains of $H$ pylori examined: their DNA type/subtype designations and distinguishing chromosomal and plasmid features

\begin{tabular}{|c|c|c|c|}
\hline $\begin{array}{l}\text { H pylori } \\
\text { strain } \\
\text { reference }\end{array}$ & $\begin{array}{l}\text { DNA } \\
\text { digest } \\
\text { typel } \\
\text { subtype }\end{array}$ & $\begin{array}{l}\text { Subtype } \\
\text { distinguishing } \\
\text { bands } \\
\text { (kilobase) }\end{array}$ & $\begin{array}{l}\text { Plasmid } \\
(M d)\end{array}$ \\
\hline $\begin{array}{l}\text { Patient A set } \\
\text { A-I, A-II } \\
\text { A-IV }\end{array}$ & $\begin{array}{l}1 \mathrm{a} \\
1 \mathrm{~b}\end{array}$ & $15 \cdot 5$ & $\begin{array}{l}3 \cdot 3 \\
3 \cdot 3\end{array}$ \\
\hline $\begin{array}{c}\text { Patient B set } \\
\text { B-I, B-IV }\end{array}$ & 2 & & - \\
\hline $\begin{array}{l}\text { Patient } C \text { set } \\
\text { C-I, C-II } \\
\text { C-III, C-IV }\end{array}$ & $\begin{array}{l}3 \mathrm{a} \\
3 \mathrm{~b}\end{array}$ & $13 \cdot 8,15 \cdot 8$ & $\begin{array}{l}7 \cdot 7 \\
7 \cdot 7\end{array}$ \\
\hline $\begin{array}{l}\text { Patient } D \text { set } \\
\text { D-I } \\
\text { D-II } \\
\text { D-III } \\
\text { D-IV }\end{array}$ & $\begin{array}{l}4 \mathrm{a} \\
4 \mathrm{~b} \\
4 \mathrm{c} \\
4 \mathrm{~d}\end{array}$ & $\mathrm{~V}^{+}$ & $\begin{array}{l}2 \cdot 7 \\
2 \cdot 4 \\
2 \cdot 4 \\
2 \cdot 4\end{array}$ \\
\hline $\begin{array}{l}\text { Patient E set } \\
\text { E-I, E-II } \\
\text { E-III, E-IV }\end{array}$ & $\begin{array}{l}5 a \\
5 b\end{array}$ & $20 \cdot 3,21 \cdot 6$ & - \\
\hline $\begin{array}{l}\text { Patient } F \text { set } \\
\text { F-I } \\
\text { F-II }\end{array}$ & $\begin{array}{l}6 \mathrm{a} \\
6 \mathrm{~b}\end{array}$ & $20 \cdot 6$ & - \\
\hline $\begin{array}{l}\text { Patient G set } \\
\text { G-I, G-IV } \\
\text { G-II } \\
\text { G-III }\end{array}$ & $\begin{array}{l}7 \mathrm{a} \\
7 \mathrm{~b} \\
7 \mathrm{c}\end{array}$ & $\mathrm{V}+$ & $\begin{array}{l}7 \cdot 7 \\
7 \cdot 7 \\
7 \cdot 7\end{array}$ \\
\hline $\begin{array}{l}\text { Patient } H \text { set } \\
\text { H-I, H-III, H-IV } \\
\text { H-II }\end{array}$ & $\begin{array}{l}8 \mathrm{a} \\
8 \mathrm{~b}\end{array}$ & $8 \cdot 4$ & $\begin{array}{l}3 \cdot 1 \ddagger \\
3 \cdot 1\end{array}$ \\
\hline $\begin{array}{l}\text { NCTC } 11638 \\
\text { NCTC } 12245\end{array}$ & $\begin{array}{r}9 \\
10\end{array}$ & & $\begin{array}{l}\text { ND } \\
\text { ND }\end{array}$ \\
\hline
\end{tabular}

^Roman numerals I and II indicate two antral isolates obtained in parallel, before treatment; III and IV indicate two subsequent antral isolates obtained in parallel, after treatment. $+V$ indicates various band differences detected. In set $D$, there were 13 band differences, and in set $G$ six band differences over the indicated size range.

+Plasmid present only in isolate $\mathrm{H}-\mathrm{I}$.

ND $=$ Not determined.

DNA type of $86 \%$ or greater (mean $93 \%$ ). Isolates within set $\mathrm{D}$ were the most heterogeneous with similarities ranging from 25 to $58 \%$ (mean $42 \%$ ). In contrast, the isolates from different patients with different DNA types

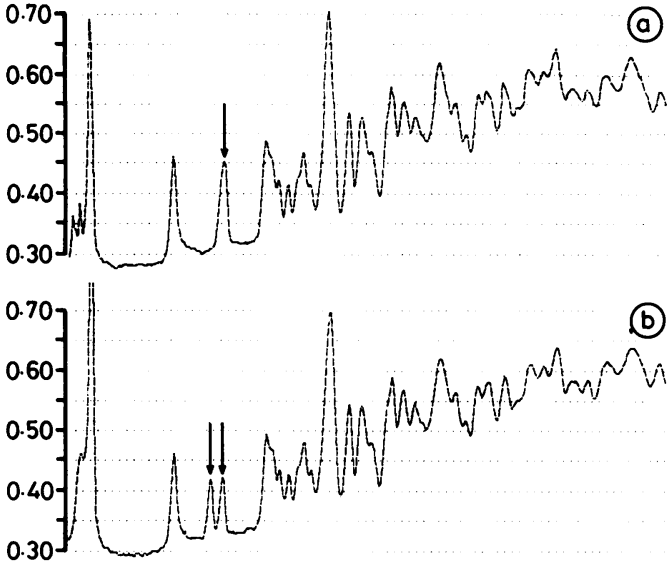

Figure 3 Densitometric traces of HaeIII digests of chromosomal $D N A$ from $H$ pylori. (a) Strain $A-I$, and (b) strain $A-I V$. The main band differences are arrowed.

had estimated similarities of $62 \%$ or less (mean $\left.43(11)^{\circ}{ }_{0}\right)$. All patient isolates had low DNA similarities to the reference strains NCTC 11638 and NCTC 12245, both of which were from different patients. An analysis of similar DNA subtype frequencies is given in table 3.

\section{Discussion}

Our DNA HaeIII restriction pattern data showed a level of genomic heterogeneity among the isolates of $H$ pylori from different patients in the United Kingdom which was consistent with that previously found in the HindIII analyses of isolates from patients in The Netherlands, ${ }^{13}$ Australia, ${ }^{14}$ and Canada. ${ }^{15}$ In the eight sets a total of eight different types and up to four subtypes in each were identified. Our results showed, however, a noticeably higher degree of similarity between isolates from the same patient than between isolates from different patients. Thus isolates from the same patient with DNA signature pattern similarities of $86 \%$ or more clearly belonged to the same DNA type. Minor band differences, however, were detected between strains in multiple sets from most patients, and generally there were at least two DNA subtypes in each set. These differences were attributed to genomic variations and not to plasmids because isolates within sets mostly had identical sized plasmids or were plasmid free.

The D set was the most heterogeneous, with the four isolates belonging to different DNA subtypes, although visual comparisons of the whole digest pattern indicated that all possessed the same general DNA pattern type. Our results were consistent with those of Majewski and Goodwin, ${ }^{14}$ who also observed differences in pairs of consecutive isolates of $H$ pylori from some of their patients. Most of our sets also contained at least two identical isolates, as described by Langenberg and co-workers, ${ }^{13}$ who found that the same strains apparently persisted in eight patients for up to two years. Our study showed, however, some heterogeneity between isolates taken from adjacent antral sites during the same biopsy. In the case 
Table 2 Estimated similarities between different HaeIII digest pattern types and subtypes of $H$ pylori

\begin{tabular}{|c|c|c|c|}
\hline \multirow[b]{2}{*}{ Strain set } & \multirow[b]{2}{*}{$\begin{array}{l}\text { DNA digest } \\
\text { type/subtype }\end{array}$} & \multicolumn{2}{|c|}{ Similarities $(\% S D)$} \\
\hline & & $\begin{array}{l}\text { Between subtypes } \\
\text { in each set }\end{array}$ & $\begin{array}{l}\text { Between type } 1 a \\
\text { and other " } a \text { " types }\end{array}$ \\
\hline $\begin{array}{l}\text { Patient } \\
\text { A } \\
\text { B } \\
\text { C } \\
\text { D } \\
\text { E } \\
\text { F } \\
\text { G } \\
\text { H }\end{array}$ & $\begin{array}{l}1 a, b \\
2 \\
3 a, b \\
4 a, b, c, d \\
5 a, b \\
6 a, b \\
7 a, b, c \\
8 a, b\end{array}$ & $\begin{array}{l}95 \\
100 \\
94 \\
25-58 \\
93 \\
96 \\
86-93 \\
97\end{array}$ & $\begin{array}{r}100 \\
50 \\
40 \\
32 \\
25 \\
36 \\
50 \\
42\end{array}$ \\
\hline $\begin{array}{l}\text { Reference } \\
\text { NCTC } \\
\text { NCTC }\end{array}$ & & - & $\begin{array}{l}33 \\
42\end{array}$ \\
\hline
\end{tabular}

Table 3 Analysis of $H$ pylori DNA subtype isolation rates

\begin{tabular}{lll}
\hline Isolate pairs & $\begin{array}{l}\text { No of } \\
\text { pairs }\end{array}$ & $\begin{array}{l}\text { Incidence of paired isolates } \\
\text { with same DNA subtype }\end{array}$ \\
\hline Parallel $^{\star}$ & 12 & $0 \cdot 50 \quad(6 / 12)$ \\
Consecutive $\dagger^{*}$ & 23 & $0 \cdot 17 \quad(4 / 23)$ \\
\hline
\end{tabular}

*Adjacent antral sites, same date of biopsy.

+Adjacent antral sites, different date of biopsy (about one month apart). Before and after treatment pairs for each of the antral sites were compared.

of the pre-treatment isolates this would suggest that genomic variants of the characteristic patient strain (such as patients $\mathrm{D}$ and $\mathrm{H}$ ) already existed in the gastric antrum. Further analysis showed that in a total of 12 pairs of parallel-that is, the same biopsy-isolates, six pairs comprised strains with identical DNA subtypes, whereas the other six pairs had different subtypes. These results also showed that it was rarer for consecutive isolates to be completely identical in their electrophoretic patterns.

We found that DNA fingerprinting, based on the use of HaeIII digest signature patterns, is a very reproducible and precise method of typing and subtyping isolates of $H$ pylori. The DNA differences observed agreed with results obtained in a separate study of one dimensional electrophoretic protein profiles (Costas $\mathrm{M}$, et al, unpublished results). As our analyses were based on comparisons of a portion of the DNA digest pattern, it is necessary to be cautious about assigning a specific similarity level to define a DNA type or subtype. For example, heterogeneity within the set of strains from patient D was apparently as great as the heterogeneity between the strains of some other patient sets. It was relatively simple, however, to identify similar DNA types by visual examination of the whole electrophoretic pattern. Our results and those of other workers $^{13-15}$ show that considerable genomic variation exists within $H$ pylori as almost every strain from different patients so far investigated has a unique digest pattern, even though species members share high levels of sequence homology. ${ }^{19} 20$

The DNA digest patterns of cultures of $H$ pylori maintained in a laboratory seem to be highly stable, ${ }^{1314}$ so we conclude that the subtype differences observed in paired isolates from the same patient, both before and after treatment, may be attributable to minor genomic nucleotide variations (possibly point mutations or inversions) resulting from drug treatment. There was no apparent link, however, between the two formulations of nitrofurantoin used and the degree of consecutive strain heterogeneity. Two or more subtypes of $H$ pylori might coexist in one patient, and by chance, different strains might have been isolated on different occasions. Thus our results support recent evidence from France suggesting that the gastric mucosa could be colonised by several strains at the same time. ${ }^{21}$

We thank Drs $\mathrm{P}$ Whorwell and D Jones for providing the isolates.

1 Goodwin CS, Armstrong JA, Chilvers T, et al. Transfer of Campylobacter pylori and Campylobacter mustelae to Helicobacter gen. nov. as Helicobacter pylori comb. nov. and Helicobacter mustelae comb. nov. respectively. Int $J$ System Bacteriol 1989;39:397-405.

2 Lee A, Hazell SL. Campylobacter pylori in health and disease: an ecological perspective. Microb Ecol Hlth Dis 1988;1:1-16.

3 Dooley CP, Cohen H. Campylobacter pylori and peptic ulcer disease. Ann Int Med 1988;108:70-9.

4 Mahoney MJ, Wyatt JI, Littlewood JM. Campylobacter pylori gastritis. Arch Dis Child 1988;63:654-5.

5 Walker SJ, Murray AE. A review of Campylobacter pylori in upper gastrointestinal disease. $\mathrm{Br} J$ Hosp $\mathrm{Med}$ 1988;40: 27-36.

6 Leunk RD, Johnson PT, David BC, et al. Cytotoxic activity in broth-culture filtrates of Campylobacter pylori. $J$ Med Microbiol 1988;26:93-9.

7 Figura N, Guglielmetti P, Rossolini A, et al. Cytotoxic production by Campylobacter pylori strains isolated from patients with peptic ulcers and from patients with chronic patients with peptic ulcers and from patients

8 Huang J, Smyth CJ, Kennedy NP, et al. Haemagglutinating activity of Campylobacter pylori. FEMS Microbiol Lett 1988;56:109-12.

9 Burnie J, Lee W, McNulty C, Dent J. Virulence of Campylobacter strains and degree of gastritis. Lancet 1988;i:302.

10 Owen RJ, Costas M, Morgan DD, et al. Strain variation in Campylobacter pylori detected by numerical analysis of one-dimensional electrophoretic protein patterns. Antoni van Leeuwenhoek 1989;55:253-67.

11 Penfold SS, Lastovica AJ, Elisha BG. Demonstration of plasmids in Campylobacter pylori. J Infect Dis 1988;157: $850-1$.

12 Tjia TN, Harper WES, Goodwin CS, Grubb WB. Plasmids in Campylobacter pyloridi. Microbios Lett 1987;36:7-11.

13 Langenberg W, Rauws EAJ, Widjojokusumo A, et al. Identification of Campylobacter pyloridis isolates by restriction endonuclease DNA analysis. J Clin Microbiol 1986;24:414-7.

14 Majewski SIH, Goodwin CS. Restriction endonuclease analysis of the genome of Campylobacter pylori with a rapid extraction method: evidence for considerable genomic variation. J Infect Dis 1988;157:465-71.

15 Shames B, Krajden S, Babida C, et al. Investigation of Campylobacter pylori strains isolated from a husband and his wife. In: Megraud F, Lamouliatte H, eds. Gastroduodenal pathology and Campylobacter pylori. Amsterdam: duodenal pathology and Campylobac

16 Pitcher DG, Saunders NA, Owen RJ. Rapid extraction of bacterial genomic DNA with guanidium thiocyanate. Lett Appl Microbiol 1989;8:151-6.

17 Owen RJ, Beck A. Evaluation of three procedures using a laser densitometer and microcomputer for estimating molecular sizes of restriction endonuclease digest fragments and application to Campylobacter jejun chromosomal DNA. Lett Appl Microbiol 1987;4:5-8.

18 Dice LR. Measures of the amount of ecological association between species. Ecology 1945;26:297-302.

19 Kado CI, Liu ST. Rapid procedure for detection and isolation of large and small plasmids. $J$ Bacteriol 1981; 145:1365-73.

20 Bukholm G, Nedenskov-Sorensen P, Bovre K. DNA-DNA hybridization incompatibility of Campylobacter pylori hybridization incompatibility of Campylobacter pylori
with other Campylobacter and Wolinella species. $A P M I S$ with other Campy

21 Beji A, Vincent P, Darchis I, et al. Evidence of gastritis with several Helicobacter pylori strains. Lancet 1989; $1402-3$ 